\title{
A GEOMORPHOLOGICAL APPROACH TO GEODIVERSITY - ITS APPLICATIONS TO GEOCONSERVATION AND GEOTOURISM
}

\author{
Michael F. ThOMAS \\ University of Stirling, Environmental Science, School of Natural Sciences, Stirling, Scotland, United Kingdom
}

Manuscript received: February 15, 2012

Revised version: March 6, 2012

\begin{abstract}
THOMAs M.F., A geomorphological approach to geodiversity - its applications to geoconservation and geotourism. Quaestiones Geographicae 31(1), Bogucki Wydawnictwo Naukowe, Poznań 2012, pp. 81-89. 8 Figs. DOI 10.2478/v10117-012-0005-9, ISSN 0137-477X.

АвSTRACT. Geodiversity is becoming widely considered alongside biodiversity by conservation agencies and has importance for geotourism. Geomorphology has a central role in understanding geodiversity, particularly at regional and local scales. By focusing on the processes that interact at the earth's surface and how they respond to external forcing, geomorphology analyses both landscape evolution and real-time changes over different timescales. Diversity reflects the complexity of process systems and history. Connectivity and sensitivity amongst landscape elements are highly varied over space and time, leading to divergence and increasing diversity over time. By using these principles within constrained chronologies of landscape change, studies of geodiversity can become a valuable tool in ecosystem management and the delivery of ecosystem services, including sustainable geotourism.
\end{abstract}

KEY WORDS: geodiversity, geoconservation, geotourism, geomorphic complexity, landscape sensitivity

Michael F. Thomas, Environmental Science, School of Natural Sciences, University of Stirling, Stirling, FK9 4LA, Scotland, United Kingdom, m.f.thomas@stir.ac.uk

\section{Introduction}

Geodiversity as a concept in the earth sciences has been formally recognized for less than two decades, and during this short period exploration of its scope and range of applications has been developed mainly by conservation agencies. Far less attention has been applied to the scientific questions raised by its use. According to Gray (2008) the term was used first in Tasmania in 1996 (see also Houshold \& Sharples, 2008), and subsequently developed by the Nordic countries (Nordic Council of Ministers 2003) to include both geological and geomorphological features and processes. Ideas relating to biological diversity were circulating widely in the 1980s and the first use of the term biodiversity is usually attributed to Wilson $(1988,1992)$. But the study of diversity in the biosphere has its roots in Darwinian analysis of the natural world and is central to the theory of evolution. It is also focused by studies of island biogeography. The theoretical compass of the term biodiversity is, therefore, often considered both broader and deeper than geodiversity. However, for Darwin and other evolutionary biologists, many essential aspects of global biodi- 
versity could only be understood by reference to the fossil record, the configuration of continents and islands, and the evidence from geology regarding the nature of past environments. It is not surprising, therefore, to find that geoconservation has become closely linked to geodiversity, and sensitive scenic sites have been recognized since the $19^{\text {th }}$ Century (Gray 2004).

\section{Geodiversity and biodiversity}

The importance of geodiversity is not confined to geoconservation, and its links to biodiversity are fundamental and yet not often emphasised. Such links occur at different scales. Schmidt (1998, for example) demonstrated how phytodiversity on Mediterranean islands reflects their physiographic complexity. In a similar manner two studies carried out respectively at the patch and landscape scales on Rhode Island, U.S.A., found clear links between geomorphological heterogeneity and biotic diversity (Burnett et al. 1998; Nichols et al. 1998). More recently, Parks and Mulligan (2010) in a paper, "on the relationship between a resource based measure of geodiversity and broad scale biodiversity patterns" argued that the environmental components of geodiversity (climate, topography, geology, hydrology) become drivers of biodiversity and can be used in broad-scale studies to predict the availability of resources (energy, water, space, nutrients), using a compound index of geodiversity, derived largely from remote sensing products. Significantly, they recognized the importance of both spatial and temporal aspects of geodiversity. These and other arguments support the inclusion of geodiversity in ecosystem management and the delivery of ecosystem services (Gordon et al. 2011).

\section{Geodiversity, geoconservation and geotourism}

Specific discussion of geotourism has been recent, and Hose (2008) has identified the 1990s as the decade of its emergence. But Gates (2010) has pointed out that geology has featured strongly in the public recognition of scenic areas in the
United States for more than a century and was embodied in the establishment of National Parks from 1872. In part national parks in the USA came about following a call to preserve wilderness areas by John Muir and others (see Nash 1967, $3^{\text {rd }}$ edtn,1982). But a Wilderness Act was not passed until 1964, and Gates notes that a peak of interest in geoconservation was reached in the 1970s with the series of Roadside Geology books.

Other popular accounts of the geology of tourist destinations were published in the 1960s and 70s. A popular account of the geology of Cape Cod was published by Strahler in 1966 and, in Africa, a popular geological history of the Ngorongoro Conservation Area in Tanzania by Pickering appeared in 1968. Notable examples from Spain are the bilingual guides to Canarian Volcanoes by Arana \& Carracedo $(1978,79)$, and the guide to granite landscapes in the Catalan province a decade later (Vilaplana 1987). It can be argued that many of these examples are more addressed to amateur and professional earth scientists on vacation than to the wider public, and it is noticeable that many national park handbooks (from different countries) say relatively little about the geology and geomorphology. With the development of mass tourism in the past few decades, publishers have largely ignored the geological basis of scenery in popular guide books, and it could be argued that we have lost ground in this context. But there have been striking new initiatives including a handsome bi-lingual (Pol./Eng.) journal of Geotourism (Geoturystyka), which has provided an outlet for detailed presentation and analysis of geosites since 2004, while the Polish Geological Review (Przeglad Geologiczny) devoted a special issue to Geotourism in Poland in which Słomka (2008) summarises the geodiversity within Poland. In most of these publications there is an emphasis on description without much discussion of geodiversity as a concept. Henriques et al. (2011) have described geoconservation as an emerging geoscience, while Hjort et al. (2010) have offered the same view of geodiversity itself. A guide to the Jurassic Coast World Heritage Site in southern England (Brunsden 2003; see also Brunsden \& Edmunds 2010) is an outstanding example of a popular exposition of the linkages between earth history, geomorphological process, geotourism and geoconservation. 
The last decades of the $20^{\text {th }}$ Century saw the rise of environmental education in many countries, but this was not always accompanied by an equal interest in the contribution of science to conservation. It can be argued that John Muir's life-long concern to preserve the Yosemite Valley (USA) amounted to an early campaign for geoconservation, but it had a strong component of romanticism rooted in the works of Thoreau. Gray (2004) has called attention to $19^{\text {th }}$ century concerns for geoconservation in the UK, but these were not formalised until 1977 with the Geoconservation Review (GCR), which called for the systematic assessment of the whole geological heritage of the UK, from first principles (Ellis 2011). Discussion of geodiversity by environmental agencies (English Nature, Scottish Natural Heritage and the British Geological Survey e.g.), has been explicit mainly since 2000. The establishment of the European Geoparks Network also dates from 2000, and was expanded to form a global network of geoparks with assistance from UNESCO in 2004.

\section{Geodiversity, geomorphic complexity and landscape sensitivity}

Ensuring that studies and applications of geodiversity recognize the changing patterns of earth features can be difficult in the face of policy requirements for fixed boundaries and inventories of resources. But as earth scientists we know that landscapes are the products of continual change on a variety of timescales, and that many processes that create diversity can also be hazardous to people, animals and plants (volcanic and hydrologic processes are two obvious examples). The sensitivity of different landscape components to change is, therefore, an important question for both developers and conservationists. This issue is also a major focus for geomorphology and other branches of science with interest in near-surface features and processes, and landscape history. Geoarchaeologists, for example, are increasingly facing earth scientists with challenging questions about the impacts of climate change, where human occupation and forest clearance have been factors for tens of millennia. It has long been accepted that woodland decline usually leads to increased sediment yields, while also arguably

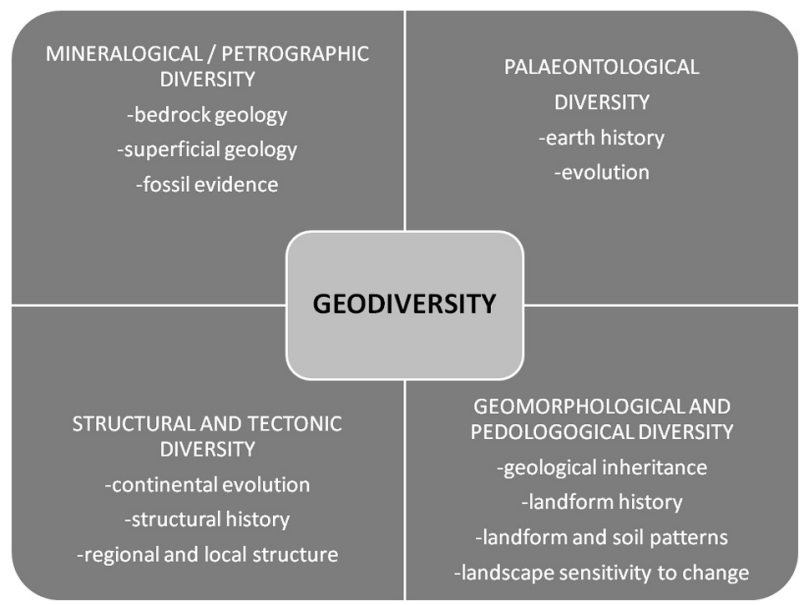

Fig. 1. Major components of geodiversity.

increasing the exposure of many communities to the dangers of debris flows.

The importance of geomorphology as a contributor to geodiversity is often neglected. The diagram below (Fig. 1) indicates how geodiversity is the outcome of many different factors. Geomorphology also has a central role to play in those aspects of geodiversity that focus on landscape change and sensitivity to change. Whether approached from an evolutionary perspective or as the arena for interacting non-linear, dynamic processes, the land surface has always been conceptualised in geomorphology as the product of cycles and systems inducing change (Fig. 2). Complexity occurs within these process systems, and morphological diversity also results from the succession of different processes systems and rates of processes over long timescales (often exceeding 106 y) (Ruxton 1968; Phillips 1999, 2007). Magmatic processes and attendant tectonism ultimately drive the evolutionary machine, in-

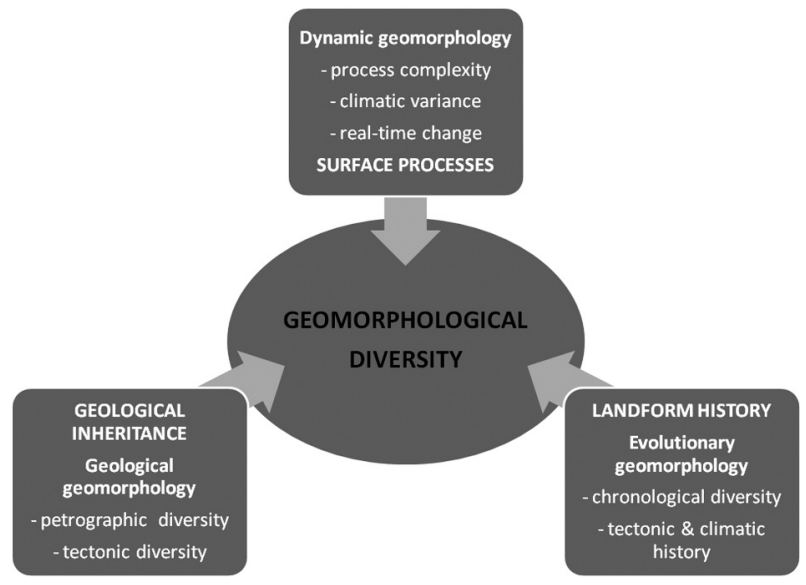

Fig. 2. Components of geomorphological diversity. 
cluding the dynamics of the atmosphere. But it is the surface and near-surface processes that interact directly with people, whether from volcanic eruption or the impacts of extreme meteorological and hydrological events. As a consequence of these interactions, inherited features occur in almost all present-day landscapes, often contributing their defining characteristics. Nowhere is this more strikingly demonstrated than in the glaciated terrain of mountains in mid to high latitudes. Yosemite is one striking example (Figs. 3, 4), but in non-glaciated terrain the same principles apply Fig. 5). At the other extreme most riverine landscapes possess an internal complexity that, while almost imperceptible to the casual observer, is expressed in patterns of ancient channels, river terraces and a buried architecture of varied sediments, all of which influence drainage and flood hazard.

Landscape sensitivity expresses the stability (resilience) or instability of process systems in response to changes in external forcing (Thomas \& Allison 1993; Phillips 1999, Thomas 2001). To the extent that these process systems support or destroy specific elements of the physical landscape, they become the agents of change that lead

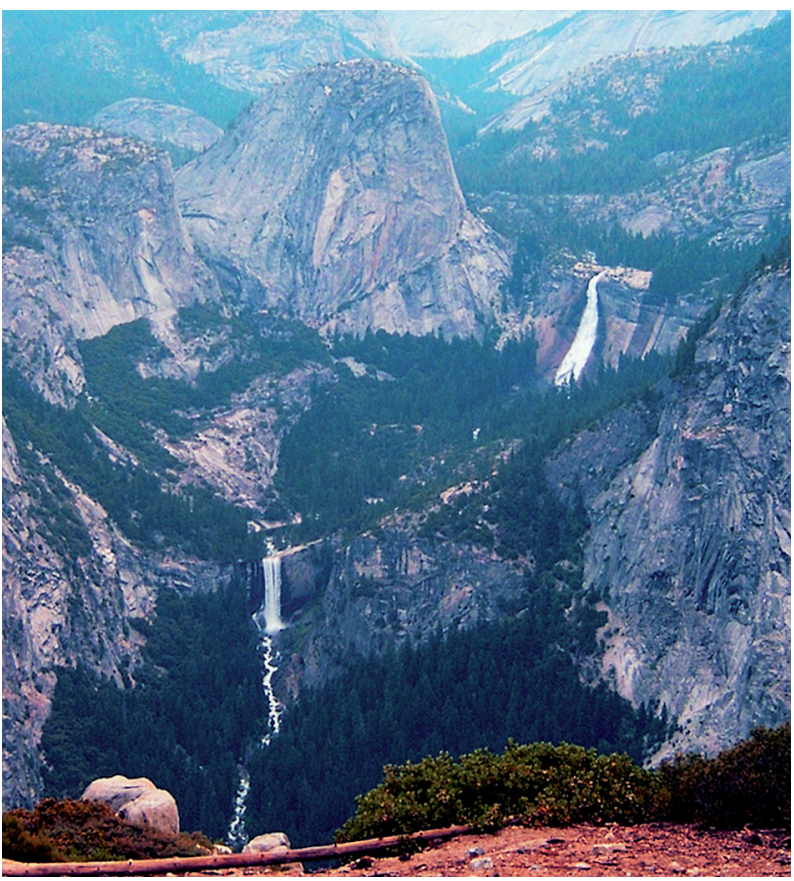

Fig. 3. View over Yosemite (Nevada and Vernal Falls on the Merced River in picture from Glacier Point), carved largely in granite bedrock yet reflecting the impacts of glaciation and de-glaciation, with rock spalling and details arising from fluvial activity (see Fig. 4). to increasing diversity of landforms. Such morphological expressions of system changes can be transient in highly sensitive and rapidly changing systems, such as bars in a river channel or cuspate forms on a beach, but they can also be persistent: when floodplains become incised to form terraces or where coastal accretion occurs. Geomorphic diversity results from divergence, usually over long time periods, of different elements in the landscape, and this phenomenon is fundamentally related to the application of forces to landscape elements (patches, facets etc) that have different resistances to change (Fig. 6). This amounts to differential erosion, and the differential lowering involved leads to fragmentation of the landsurface and inheritance of features that respond and change very slowly. This well understood maxim in geology can have extreme results, especially in ancient landscapes, where some persistent forms

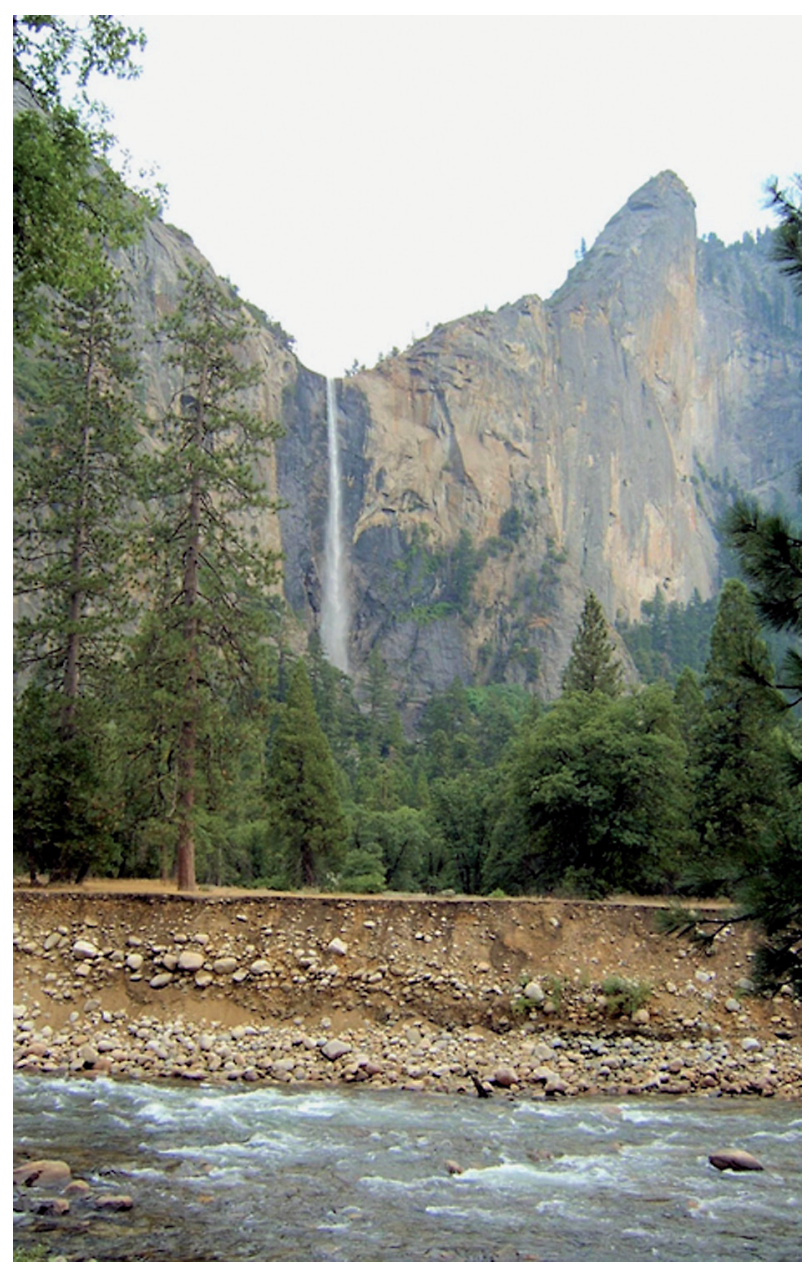

Fig. 4. The Merced River in the Yosemite Valley with the Bridalveil Falls. Glacial erosion and the accumulation of flood gravels dominate the scene. 


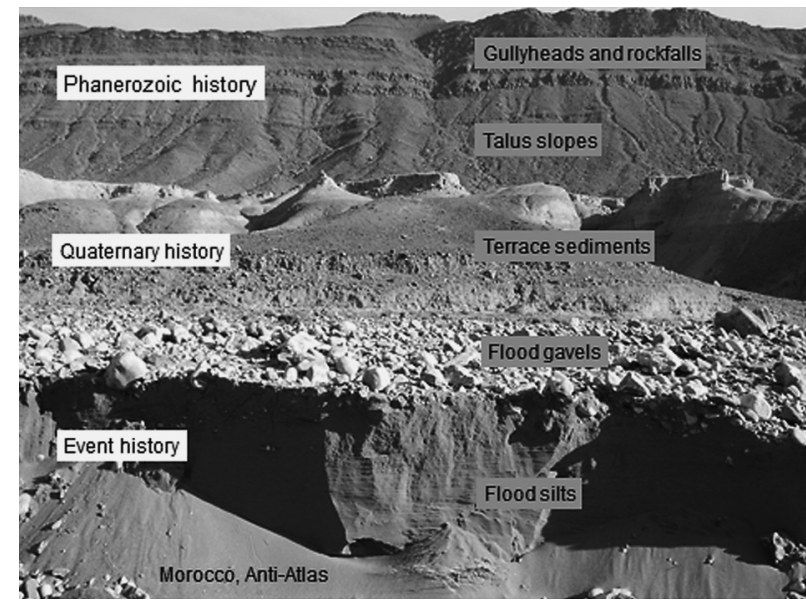

Fig. 5. Internal complexity (diversity) within the preSaharan zone of the Anti-Atlas basin-and-range in southern Morocco.

have indeterminate ages (possibly $10^{7} \mathrm{y}$ ). Famous examples include Uluru (formerly Ayer's Rock) in central Australia (Twidale 2010) and the Spitzkoppe in Namibia (Migon 2010). On the other hand the Grand Canyon (USA), remarkably, has an age limited to 4-6 my by geological evidence (see Dexter 2010), while constructional, volcanic forms of large size can be formed within a few years: Paricutin (Mexico) first erupted in 1943 and had exceeded $380 \mathrm{~m}$ in height by the end of 1947 (see Alcántara-Ayala 2010).

Without the restless stimulation of the geosphere by uplift and dissection, it is arguable that geodiversity would become reduced over long time periods $\left(10^{6}-10^{8} \mathrm{y}\right)$ as a function of the 'geographical cycle' of Davis (1899), while it is amplified by climatic shifts and crises such as

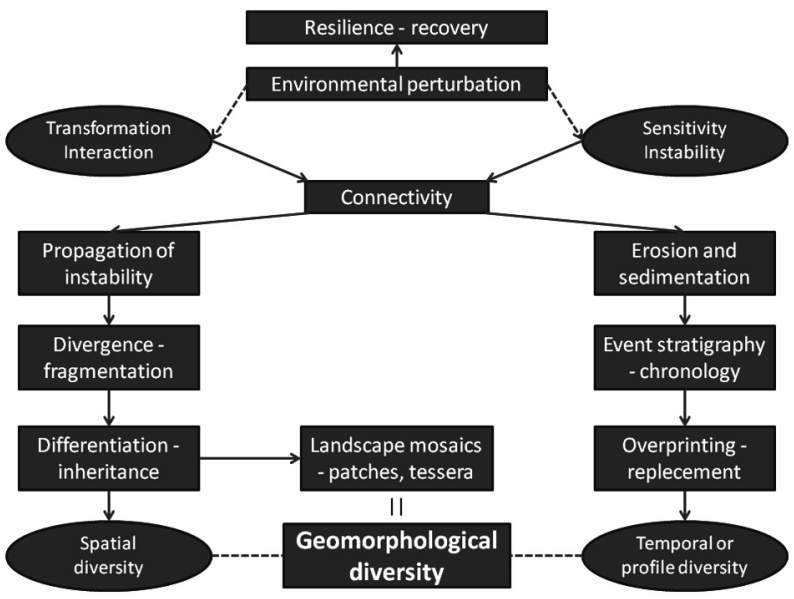

Fig. 6. Geomorphological diversity as a function of landscape sensitivity, and divergence in response to non-linear, dynamic processes operating on different temporal and spatial scales (adapted from Thomas 2001). glaciation (Croll-Milankovic cycles, $10^{5} \mathrm{y}$ ). These arguments apply to erosional landscapes; where basin subsidence occurs, successive waves of sedimentation can produce extensive plains, in which the older history of the landsurface is repeatedly overprinted by fresh deposition. Geodiversity in these landscapes is revealed mainly in the sedimentary pile, although subsequent uplift and erosion may have resulted in detailed topographic expression.

\section{The role of connectivity between landscape elements}

Connectivity or coupling, especially as between hillslopes and channels in fluvial systems, links geosites (or geomorphosites) to the concept of sensitivity and to rates of change (Harvey 2002; Chiverrell et al. 2009), and should also inform the approach to geoconservation. Ineffective or limited coupling is illustrated by the persistence of forms and deposits inherited from glaciation and de-glaciation, which still dominate many parts of the Earth (Ballantyne 2002). These examples demonstrate that the relaxation times needed to bring new landscapes into equilibrium following the impact of major climatic changes during the Quaternary far exceed the duration of post-glacial time (11 ky). The changes wrought by post-glacial readjustment, however, can still be remarkable. Massive rock falls, and rotational landslides, for example, are found throughout the Scottish Highlands (Ballantyne 1986, Jarman 2006) and in many other parts of glaciated Europe. Most of these occurred during the first half of the Holocene, and more recent forms tend to be on a smaller scale. An absence of effective coupling is also found in arid and semi-arid areas, where linear erosion, often due to flash floods, dominates over slope adjustment (Fig. 5). It is in the humid landscapes of the World that water moves across and through the soil layers effecting change by transferring sediment downslope, and often triggering hillslope failures. The features in Figure 7 are based on experience in tropical savannas, where connectivity between hillsopes and valley floors is seasonal and limited in extent, many features dating to the Quaternary (Thomas \& Murray 2001). 
But perhaps more fundamental still are major tectonic landforms such as the great fault systems of east Africa that have created some of the most sharply delineated landforms $n$ earth, along with the fresh volcanic forms that accompanied the rifting, and are replicated widely around the globe. The active tectonism of some continental islands, such as Taiwan, has also proceeded at rates that far outstripped the combined rates of denudation processes throughout the Quaternary. The spectacular Taroko Gorge that plunges to a depth of more than $1000 \mathrm{~m}$, following lithological and structural weaknesses, is but one example of linear erosion far outpacing the rates of wider surface lowering. World-wide, the geomorphic diversity of landscapes is frequently a result of landscape components being 'left behind' by the processes of denudation following major geological events, such as the post-Triassic break-up of the continental plates to create the Atlantic and Indian oceans or the consequential collision of the drifting plates to form the Himalayan mountains.

From the perspective of geotourism, many viewpoints attract tourists because there are abrupt breaks in the landsurface, whether isolated summits (including volcanoes and karst towers), precipitous plateau edges, or gorges. These few categories embrace features such as islands, inselbergs (of many kinds), desert canyons and fjords. Other sights impress by their inherent complexity, such as the countless granite domes

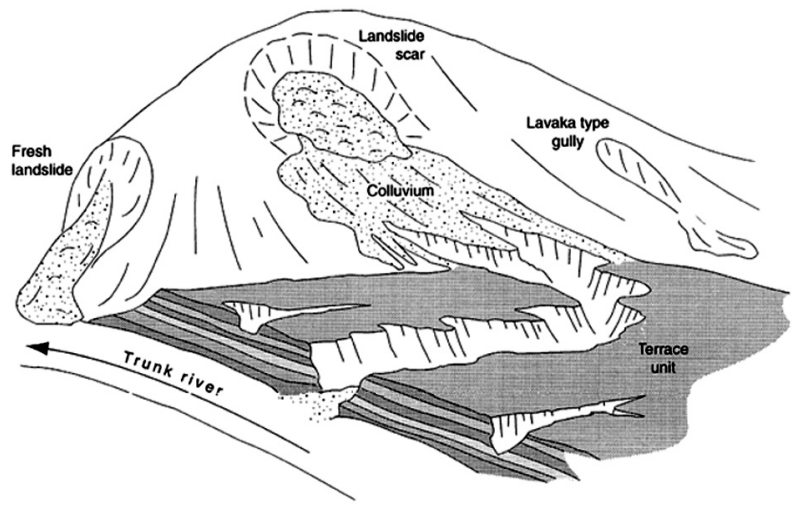

Fig. 7. Features of an African savanna landscape based on observations in eastern Zambia. Most major landslides are fossil and exceed 200ka (Thomas \& Murray 2001); gullies in the river terraces (mostly from last glacial cycle) are active - subject to ephemeral surface flows and tunnel collapse in sodic soils. Tourism based on wildlife viewing is strongly influenced by these and other landscape details. and tors of the Matopos Mountains in Zimbabwe, the sandstone karst of the Bungle Bungle in central Australia (Young 2010), also the Namib Sand sea (Goudie 2010), and of course the glaciated 'alpine' peaks of great mountain ranges.

\section{Landscape sensitivity and geoconservation}

A primary concern of geoconservation has always been to protect critical sections, usually for their display of fossils, stratigraphies or structures. But a broader view embraces landscape features (landforms) and their associated plant covers, and this involves an understanding of ecological habitats and their boundaries (essentially aspects of biodiversity). Inevitably this must also include the processes that maintain, but could also degrade or destroy, the visual harmony. This area of enquiry is where geodiversity becomes linked to climate fluctuation and change, and extreme events. Crawford (2008) has eloquently demonstrated the importance of margins in the study of plant distributions. Many of his margins are in fact geomorphic and edaphic boundaries (cliff and scree; dune and slack; hydrological boundaries, e.g.); others are determined by rock type or by climate (especially altitudinal limits). Some of these are highly sensitive to climate and or sea-level changes. Many boundaries can also be overwhelmed, even obliterated, by extreme events: such as landslides, debris-flows affecting fans, coastal storm surges. The Jurassic Coast World Heritage Site in southern England is notable for its display of active and changing coastal forms, including large landslides and is a dynamic example of change at the ocean, atmosphere and land interface (Brunsden \& Edmonds 2010, 211). It is also a world-famous fossil locality and illustrates many of the principles discussed here, and also illustrates important aspects of the history of geoscience.

Most issues in geoconservation go beyond site specific considerations as demonstrated above, and need to be considered at the landscape scale. The concept of landscape is central to geographical enquiry and it was a geographer, Troll (1963) who first developed ideas in landscape ecology (Landschaftsöekologie) for land management. 
This field of study, with its concern for patterns, processes and scales, has since developed as a separate specialism (Wiens \& Moss 2005, Thomas 2005). Geodiversity at the landscape scale is frequently expressed in numerical terms (Cañadas \& Flaño 2007; Ehsani \& Quiel 2008; Hjort \& Luoto 2010; Ruban 2011, e.g.), but it is doubtful whether existing schemes can yet be considered robust or widely applicable. However, Zwoliński (2010) has taken a broader view and made a distinction between static geodiversity, measured at a particular place and time, and dynamic geodiversity estimated from a proxy of landform energy using measures of local relief. He also introduced measures of landform fragmentation and preservation, all of which offer pointers for future progress.

There will always be exceptional or iconic landforms that command attention and attract visitors. Many, such as the Sugar Loaf in Rio de Janeiro or the Half Dome at Yosemite have near neighbours of similar morphology and geology and emerge from a complex and geodiverse landscape of wide extent. Others rise abruptly from plains, or as islands and have no close neighbours. In central Australia the Olgas, or Kata Tjuta, and Uluru (Ayer's Rock), are separated by more than $20 \mathrm{~km}$ of plains and are not readily contained in the same view. The island of Anak-Krakatau (Indonesia) is a singular feature that records repeated volcanic eruptions, each increasing the local geodiversity, and also the developing biodiversity, where the surface has remained undisturbed (Fig. 8).

Such examples emphasise the importance of scale in studies of diversity (bio- or geo-), and their applications. At national, continental and global scales rarity becomes an issue both bio- and geodiversity, and single features such as those illustrated above become highly valued. It is often the iconic landform or scenic outlook that people flock to view, though harmonious combinations of morphology and human occupation and land-use patterns can also be a motive for visiting many areas. In fact many different aesthetic considerations enter into visitor attraction, and icy wastes, vast dune fields, and riverine landscapes of complex channels and dense vegetation, all but concealing riverside villages (Amazonia e.g.) may all prove attractive, and have featured fre-

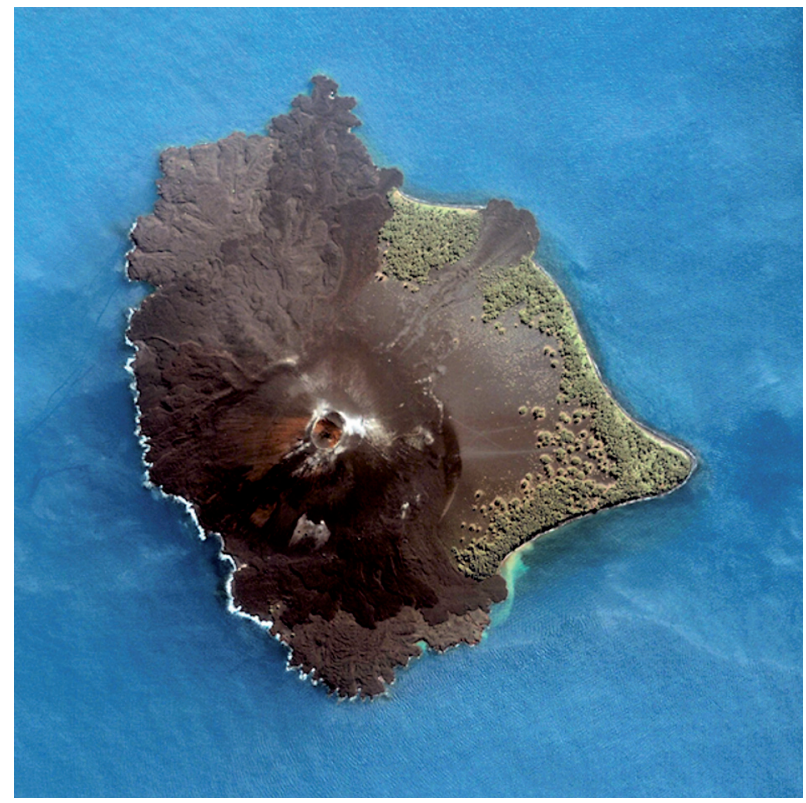

Fig. 8. The island of Anak-Krakatau, formed after the explosive destruction of Krakatau in 1883. Wilson (1988) was impressed by the developing biodiversity as seen from the shoreline in the SE, on the undisturbed volcanic ash soils.

But the space image (NASA 2005) shows how repeated eruptions have limited plant colonisation elsewhere, whilst increasing the geodiversity. Such relationship emphasise the complexities of biodiversity-geodiversity relationships, and the influence of scale in the assessment of diversity. NASA Earth Observatory 2005

quently in the cinema. Many such considerations come together in the themes identified by IUCN for geological and geomorphological World Heritage Sites (see Badman 2010, Table 37.1).

\section{Summary and conclusions}

1. Geodiversity exists at all spatial scales, and local, regional and global geodiversity can have different connotations. At the landscape scale geomorphology has a major role in defining and understanding geodiversity. Geomorphology aids the understanding of the evolution of landscapes through time and identifies sensitive elements of the landscape that are subject to instability and change.

2. Many landscapes that attract tourists are unique on a global scale, but they may be extensive and internally complex. The Grand Canyon and the Yosemite Valley are examples from the USA. The Jurassic Coast World Heritage Site in the UK is another. In the survey of World landscapes by Migoń (2010), several 
complex areas are included from Africa: including the Drakensberg Escarpment (RSA), Namib Sand Sea (Namibia), and the Afar Triangle (Ethiopia, Djibouti). Singular landforms often come to represent wider areas of interest and become the focus of tourism: the Half Dome at Yosemite is an example; Spitzkoppe (Namibia) is another. Some singular features command attention within otherwise modest surroundings: the Iguazu Falls (Argentine, Brazil) and Victoria falls (Zambia, Zimbabwe) are examples, and Uluru (Ayer's Rock, central Australia) despite neighbouring massifs appears isolated and commands attention for this reason. Many of the World's great volcanoes are features of this kind.

3. Indices of geodiversity now exist, mostly based on relief parameters (Cañadas \& Flaño 2007; Ehsani \& Quiel, 2008; Hjort, 2010; Ruban, 2011, e.g.), but have so far not been widely applied. Detailed quantification of terrain must also link to the complexity of geomorphic systems and history (Figs. 2, 3) for management purposes, and indices need to be linked to sensitivity to changing conditions and to resource availability (Parks \& Mulligan, 2010).

4. Geodiversity has the potential to become a valuable tool in many contexts. However, earth scientists working in this field need to embrace the dynamics of landscape change and the differential response of landscape components, particularly to external forcing, whether from land use or management change, or from global climate change.

5. Landscapes possessing high internal diversity usually contain forms and materials of widely varying ages, and sensitivities to change. Such a geodiverse terrain with varied elevation, slope, aspect, and materials with different hydrodynamic properties, will provide a wide range of habitat niches which will promote biodiversity.

6. Similar properties contribute to the attractiveness of many tourist destinations, but of exceptional (possibly iconic) landforms occurring as singular features frequently act as magnets, giving rise to unwelcome visitor pressures. Offering visitors a wider understanding of the topographic and geological setting can act to disperse such pressures, providing that access to viewpoints is available.

7. Finally, it is important that geodiversity is employed within a multi-disciplinary framework, where the human factors (and artifacts) are given due emphasis: from archaeological sites and monuments to land-use change and management.

\section{References}

Arana V. \& CARracedo J.C., 1978/9. Los Volcanes de Las Islas Canarias (Canarian Volcanoes): 1. Tenerife, 2. Lanzerote y Fuerteventura, 3. Gran Canaria. Editorial Rueda, Madrid: 151, 176, 175.

BADMAN T., 2010. World Heritage and Geomorphology. In: Migon P. (ed.), Geomorphological Landscapes of the World. Springer, Dordrecht: 357-368.

BALLANTYNE C.K., 1986. Landslides and slope failures in Scotland: a review. Scottish Geographical Magazine, 102: 134-150.

BallantYNe C.K., 2002. Paraglacial geomorphology. Quaternary Science Reviews, 21: 1935-2017.

BRunsDEn D. \& Edmunds R., 2010. The Dorset and east Devon Coast: England's Geomorphological World Heritage Site. In: Migon P. (ed.), Geomorphological Landscapes of the World. Springer, Dordrecht: 211-222.

Brunsden D. (ed.), 2003 (2nd edtn 2008). A Walk Through Time. The Official Guide to the Jurassic Coast (World heritage Site). Coastal Publishing, Wareham, UK.

Burek C.V. \& Prosser C.D. (eds.), 2008. History of Geoconservation. Geological Society Special Publication, 300.

Burnett M.R., August P.V., Brown Jr. J.H. \& Killingbeck K.T., 1998. The influence of geomorphological heterogeneity on biodiversity: I. A patch-scale perspective. Conservation Biology, 12: 363-370.

Cañadas S. \& Ruiz-Flaño E., 2007. Geodiversity: Concept, assessment and territorial application. The Case of TiermesCaracena (Soria). P. Boletin de la A.G.E., 45: 389-393.

Chiverrell R.C., Foster G.C., Marshall P., Harvey A.M. \& ThOmAs G.S.P., 2009. Coupling relationships: Hillslope fluvial linkages in the Hodder catchment, NW England, Geomorphology, 109: 222-235.

Crawford R.M.M., 2008. Plants at the Margin: Ecological Limits and Climate Change. Cambridge University Press, Cambridge.

Davis W.M., 1899. The geographical cycle. Geographical Journal, 14: 481-504.

Dexter L.R., 2010. Grand Canyon: the Puzzle of the Colorado River. In: Migoń P. (ed.), Geomorphological Landscapes of the World. Springer, Dordrecht: 49-58.

EHSANi A.H. \& QuiEL F., 2008. Geomorphometric feature analysis using morphometric parameterization and artificial neural networks. Geomorphology, 99: 1-12.

ELLIS N., 2011. The Geological Conservation Review (GCR) in Great Britain - Rationale and methods. Proceedings of the Geologists' Association, 122: 353-362.

GAtes A.E., 2006. Geotourism: A Perspective from the USA. In: Dowling R. \& Newsome D. (eds.), Geotourism. Elsevier, Ltd.: 157-179. 
Gordon J.E., Barron H.F., Hansom J.D. \& Thomas M.F., 2011. Engaging with geodiversity - why it matters. Proceedings of the Geologists' Association, 122.

Goudie A., 2010. The Namib Sand Sea: Large Dunes in an Ancient Desert. In: Migoń P. (ed.), Geomorphological Landscapes of the World. Springer, Dordrecht: 163-170.

GrAY M., 2004. Geodiversity: valuing and conserving abiotic nature. John Wiley \& Sons, Chichester.

Gray M., 2008. Geodiversity: The origin and evolution of a paradigm. In: Burek C.V. \& Prosser C.D. (eds.), The History of Geoconservation. Geological Society, London, Special Publication: 31-36.

Harvey A.M., 2002. Effective timescales of coupling in fluvial systems. Geomorphology, 44: 175-201.

Henriques M.H., Pena dos Reis R., Brilha J. \& Mota T., 2011. Geoconservation as an Emerging Geoscience. Geoheritage, 3: 117-128.

Hjort J., \& Luoto M., 2010. Geodiversity of high-latitude landscapes in northern Finland. Geomorphology, 115: 109-116.

Hose T.A., 2008. Towards an history of geotourism: definition, antecedents and the future. In: Burek C.V. \& Prosser C.D. (eds.), History of Geoconservation. Geological Society, London, Special Publication, 300: 37-60.

Houshold I. \& SHARples C., 2008. Geodiversity in the wilderness: a brief history of geoconservation in Tasmania. In: Burek C.V. \& Prosser C.D. (eds.), History of Geoconservation. Geological Society, London, Special Publication, 300: 257-272.

JARMAN D., 2006. Large rock slope failures in the Highlands of Scotland: Characterisation, causes and spatial distribution. Engineering Geology, 83: 161-182.

Migoń P., 2010. Sptizkoppe: The World of granite landforms. In: Migoń P. (ed.), Geomorphological Landscapes of the World. Springer, Dordrecht: 155-162.

Nichols W.F., Killingbeck K.T \& August P.V., 1998. The influence of geomorphological heterogeneity on biodiversity: II. A landscape perspective. Conservation Biology, 12: 371-379.

Nordic Council of Ministers, 2003. Diversity in Nature. Nordic Council of Ministers, Copenhagen.

PARKS K.E., \& Mulligan M., 2010. On the relationship between a resource-based measure of geodiversity and broad scale biodiversity patterns. Biodiversity and Conservation, 19: 2751-2766.

PHILLIPS J.D., 1999. Earth Surface Systems. Blackwell, Oxford.
PhILLIPS J.D., 2007. The perfect landscape. Geomorphology, 84: 159-169.

PiCKERING R., 1968. Ngorongo's Geological History. Ngorongoro Conservation Unit, Arusha, Tanzania.

RUBAN D.A., 2010. Quantification of geodiversity and its loss. Proceedings of the Geologists' Association, 121: 326-333.

RuxTON B.P., 1968. Order and disorder in landform. In: Stewart G.A. (ed.), Land Evaluation. Macmillan, Melbourne: 29-39.

SchmidT T., 1998. Phytodiversity on Mediterranean islands. Geographische Rundschau, 50: 680-688.

SŁomKa T., 2008. Geodiversity of Poland. Przegląd Geologiczny (Polish Geological Review), 56(8/1): 584-587.

Strahler A.N., 1966. A Geologist's View of Cape Cod. Paranassus, Massachusetts.

Thomas D.S.G. \& Allison R.J. (eds.), 1993. Landscape Sensitivity, John Wiley, New York.

Thomas M.F. \& Murray A.S., 2001. On the age and significance of Quaternary alluvium in eastern Zambia. Palaeoecology of Africa, 27: 117-133.

THOMAs M.F., 2001. Landscape sensitivity in time and space an introduction. Catena 42: 83-98.

Thomas M.F., 2005. Landscape sensitivity and timescales of landscape change. In: Wiens J.A. \& Moss M.R. (eds.), Issues and Perspectives in Landscape Ecology. Cambridge University Press, Cambridge, UK: 131-151.

Troll C., 1963. Landscape Ecology. Publication of the ITCUNESCO Centre for Integrated Surveys, Delft.

TwidAle, C.R., 2010. Uluru (Ayer's Rock) and Kata Tjuta (The Olgas): Inselbergs of Central Australia. In: Migoń P. (ed.), Geomorphological Landscapes of the World. Springer, Dordrecht: 321-332.

Vilaplana J.-M., 1987. Guia dels Paisatges Granitics e dels Paisos Catalans. Kapel SA, Barcelona: 182.

Wiens J.A. \& Moss M.R., 2005. Issues and Perspectives in Landscape Ecology. Cambridge University Press, Cambridge, UK.

WiLson E.O. (ed.), 1988. Biodiversity. National Academy of Science, Smithsonian Institution, U.S.A.

Wilson E.O., 1992. The Diversity of Life. Norton, New York, U.S.A.

Young R.W., 2010. Bungle Bungle: Tower karst in Sandstone. In: Migon P. (ed.), Geomorphological Landscapes of the World. Springer, Dordrecht: 333-340.

ZwolińsKI Zb., 2010. The routine of landform geodiversity map design for the Polish Carpathian Mts. Landform Analysis, 11: 77-85. 